\title{
An Investigation of the Determinants of Savings and Investment in Nigeria
}

\author{
Adelakun, O. Johnson \\ Department of Economics, College of Social Sciences \\ Joseph Ayo Babalola University, Nigeria \\ Tel: 234-80-6901-9949_E-mail: joadelakun@yahoo.co.uk
}

Received: June 12, $2015 \quad$ Accepted: October 10, $2014 \quad$ Published: December 7, 2015

doi:10.5296/ieb.v1i2.8688

URL: http://dx.doi.org/10.5296/ieb.v1i2.8688

\begin{abstract}
This study examined the relationship between savings, investment and economic growth. A corollary of the work is the determination of which of the inputs of production contributes more to economic growth in Nigeria. The study makes use of time series data spanning twenty-nine years using error correction model. The result shows a positive relationship between savings, investment and economic growth in Nigeria. Of the determinants of savings considered in the study, inflation rate contributes negatively to saving, while interest rate positively affect saving. All these confirm economic theory. The striking feature of the study however is the confirmation of the impact of labour on economic growth, which according to the study far outweighs the contribution of capital.
\end{abstract}

Keywords: Savings, Investment, Error correction mechanism, Economic growth 


\section{Introduction}

Aggregate saving and investment in any economy are dependent on a number of interdependent variables. For economic planning purposes, it is important that economic planners have a true and fair idea about the quantum of saving and investment, the behavior of people towards saving and investment and the method by which saving can be improved for investment decisions. Economic planners also need to know about the motives of saving and investment in order to frame appeals accordingly. Understanding saving and investment preference would also help design and implement saving instruments which effectively stimulate saving. Given the present weight of the household sector in total saving, to step up the saving in the economy would require a stepping up of the saving rate in the household sector. Hence, there is the need to carefully understand the determinants of both the household saving rate and the saving pattern".

Savings and investment has been emphasized by Economists as a precondition for the growth and development of countries. There has been increasing awareness that the faster the rate of investment, the greater the rate of capital formation, which ultimately promote growth and development (Thilwal, 1979). Saving is normally considered in economics as disposable income minus personal consumption expenditure. In other words, it is regarded as income that is not consumed by immediately buying goods and services. For the purpose of this study, it must be emphasized that "saving" refers to deposits in saving accounts. Thus, the studies focuses on financial saving of households held by banks, microfinance institutions, Esusu groups and other saving avenues.

The above definition is clear that saving is closely related to investment. Saving can therefore be vital to increasing the amount of capital available. Meanwhile increased saving is a necessary but not a sufficient condition for investment. Of course Savings is a strategic variable in the theory of economic growth hence its role as a determinant of economic growth has been emphasized by classical economists like Adam Smith and David Ricardo. In many developing economies particularly Africa, saving and investment are necessary engines for capital formation hence economic growth.

Funding investment required for economic growth, the economy needs to generate sufficient saving or it should borrow abroad. Nevertheless, borrowing from abroad may not only have adverse effects on the balance of payments as these loans will have to be serviced in the future but it also carries a foreign exchange risk. So, sufficient domestic saving is necessary for economic growth because it also forms part of the most important issues in development economics, and for developing countries, are how to stimulate investment, and how to bring about an increase in the level of saving to fund increased investment. In fact, the crucial role of domestic savings mobilization to the sustenance and reinforcement of the saving-investment-growth chain in developing countries has preoccupied development economists for decades (Lewis, 1970). Given this, the main thrust of this study is to empirically investigate the determinants of savings and investment in the Nigerian economy. This study becomes crucial in the light of the need to provide necessary insight on how to foster rapid growth and development of the economy. 


\section{Ml Macrothink}

Despite the above awareness, the situation in Nigeria is such that the saving ratio is so low. This situation has affected productivity growth in Nigeria. Corroborating this, Iyoha (1998) maintained that the negative growth in real GDP in the mid-1980s could be attributed to a host of factors of which decline in investment and savings are a major factor. Nnanna (2003) also maintained that savings and investment culture in Nigeria is very poor relative to most economies of the world. Nnanna indicated that the domestic savings which averaged 15.7 percent of GDP during the period 1986-1989 declined significantly to 6.0 per cent between 1990-1994 while in 1996 and 1999, this ratio stood at 13.2 per cent and 14.5 percent respectively. Is there a relationship between Savings and Investment in Nigeria economic growth? What determines savings and investment in the Nigeria economic growth? What are their effects on the Nigerian economic growth? In the light of this, the main research questions, which this study intends to investigate, include: What are relevant variables affecting aggregate savings behaviour in the Nigerian economy? What are the determinants of aggregate investment in Nigeria? How could saving and investment culture be promoted in the Nigerian economy? Providing empirical evidence on the above questions becomes necessary in the light of the need to promote the growth and development of the Nigerian economy.

The broad objective of this study is to empirically examine the determinants of savings and investment in Nigeria. The specific objectives, which this study intends to pursue, are to:

i. review the trend of savings and investment in Nigeria;

ii. to ascertain the determinant of savings in the Nigerian Economy;

iii.to ascertain the determinant of investment in the Nigerian Economy;

iv.Proffer policy measures for boosting savings and investment in Nigeria;

v. To examine and evaluate the impact of savings and investment on the Nigerian economy growth.

To serve as a tentative guide in the course of this study the following null hypothesis are formulated: There is no relationship between aggregate savings and real disposable income as a determinant of savings. There is no statistical significant relationship between the level of saving and investment in Nigeria economic growth. There is no statistical significant relationship between saving and the Nigeria economic growth. There is no statistical significant relationship between investment and the Nigeria economic growth.

\section{Empirical Review of Literature}

Several empirical studies focusing on the determinants of savings have been conducted in both developed and developing countries, Nigeria inclusive.

Reichel (1991) empirically analyzed the relationship between the real interest and savings in Nigeria. In an attempt to achieve the objective of his study, he specified the average propensity to save as a function of factors such as the level of income, real interest rate and previous level of APS. Reichel further regressed real growth rate of time and savings deposits 
on the real interest rate and per capital real income. The result of this study indicated that: (i) real interest rate is positively related to gross domestic and financial savings; (ii) output is significantly and positively related to gross domestic savings but only positively related to financial savings; (iii) output growth rate and investment-output ratio show negative but significant relationship.

Soyibo and Adekanye (1991) tested the determinants of savings in Nigeria. The result of this study indicated that lagged aggregate savings ratio as well as current GDP, foreign savings and ex post real interest rate were significant in savings determination in Nigeria. The nonsignificance of the income variable in the model specified could have resulted from multicollinearity since most of the equations had high $\mathrm{R}^{2}$ values.

With respect to investment, it was found that (i) changes in industrial output had positive effect on aggregate investment; (ii) minimum rediscount rate and treasury bill rate, once again, had opposite effects on the level of investment, being positive and negative respectively; (iii) the exchange rate had positive effect on fixed investment, negative influence on investment in new issues market and a positive effect on investment in the secondary securities market. Finally, SAP has a negative effect on real investment but a positive effect on financial investment. In the light of the deregulation of interest rates in Nigeria, Uchedu (1993) examined the impact of this policy reversal on savings and investment in the Nigerian economy. The econometric investigation of this study revealed that (i) nominal savings interest rate is the main determinant of financial savings in Nigeria; (ii) gross national savings in positively and significantly explained by real savings rate and other variables; (iii) gross domestic investment is negatively and significantly related to prime lending rate; and (iv) financial savings explained 98.3 per cent of the variation in bank loans and advances. This study recommended the harmonization of interest rate policy in order to stimulate saving without strangling investment demand.

Chete (1997) investigated the determinants of private savings in Nigeria. In this study, the core private savings measured as gross domestic savings less public savings was estimate. The explanatory variables included in the model include level of per capital income, real interest rate, growth rate of terms of trade, degree of financial depth, macroeconomic stability (mirrored by annual rate of inflation), public savings, government consumption expenditure, external debt service ratio, and dependency ratio. The results of this study repudiated the efficacy of financial liberalization as a tool for mobilization private savings in Nigeria. The study further substantiated the adverse effects of an external debt overhang and terms of trade deterioration on private savings. The author recommended an enhancement in per-capital income and a stable macro economy to facilitate savings in the Nigerian economy.

The CBN (2010) reviewed the various factors influencing the behaviour of interest rates in an economy. Prominent among these factors were savings, investment, inflation, government spending, monetary policy, and taxation. The CBN further maintained that savings constituted the source of credit while investment represented the main demand for credit and as such, the amount of savings by individuals, businesses and government policy partly determine the level of interest rates. In another study, Nyong (2000) attempted to identify the 
critical factors that influence savings for capital formation and growth in Nigeria. The study examined the macroeconomic importance savings in Nigeria, the rationale for the financial liberalization and the adjustment programs adopted in Nigeria to correct the perceived distortions in the Nigerian economy. The study found that capital inflows are detrimental to national savings, all things being equal. The study also indicated that taxation on income, expansion of bank branch offices, real interest rates and financial liberalization, may not lead to increase in savings mobilization in Nigeria.

Nnanna (2003) compared the trends of aggregate savings and investment in Nigeria with other countries of the world. The author identified recent efforts that have been put in place to promote savings and investment culture in Nigeria. The identified measures include: National saving certificate (NSC), floatation of federal government long-term bonds, introduction of new pension scheme, and promotion and sustenance of macroeconomic stability. In spite of the significant efforts made by authorities to enhance the savings culture of Nigerians, Nnanna noted that the fundamental issues militating against effecting savings and investment culture in Nigeria has remained financial sector distress, high inflationary expectation, low yields on investment and inappropriate institutional structures.

According to Oyaromade (2005), the effect of financial sector reforms on financial savings in the Nigerian economy. This study becomes important in the light of the need to assess the performance of financial liberalization in the Nigerian economy. Using the error correction modeling technique, the author estimated a saving equation with four explanatory variables. They include the log of consumer price index, log of GDP, log of national savings and degree of monetization of the economy. Results of this study indicated that while interest rate exerted positive influence on financial savings, the consumer price index had a negative influence on savings. The gross domestic product and the financial department variable affected savings positively. The author concluded that financial reform in Nigeria had resulted in higher financial deepening and that saving had responded positively to changes in financial variables.

\section{Methodology}

\subsection{Determinants of Savings}

The theoretical basis for the determinants of saving starts from the classical theory. According to the Classists, people that receive income do not spend their entire income on the purchase of consumption goods; they save a part of their current earnings for future spending. This implies that a part of national income leaks out of the aggregate expenditure stream in the form of saving. Except that part of income, which is saved is channeled back into the aggregate expenditure stream in the form of investment spending, the aggregate income and output will fall below the full employment level and the Say's Law of Markets will be invalidated (Vaish, 2003). To the classical economists, saving is interest-elastic i.e. a change in the rate of interest brings about either an increase or decrease in the level of savings; which depends on whether it is a positive or negative change in interest rate and is a positive function of the rate of interest. This could be written explicitly as: 


$$
S=f(r) ; \text { and } \frac{\mathrm{dS}}{\mathrm{dr}}>0
$$

Keynes argued that saving is not so responsive to interest. He maintained that it would be wrong to always conclude that more would be saved at a higher rate of interest. According to him, if the level of income is low and below the break-even level, i.e. at the point where the income of the individual is just equal to the individual's consumption purchases. An important innovations that Keynes made in his General Theory of Employment, Interest and Money (1936) was to link, for the first time, consumption (and therefore saving) to the level of income through the concept of the consumption (or savings) function. Moreover, there is the suggestion that the consumption or savings function is non-proportional; that is, that the rich (people or countries) consume proportionately less, and save proportionately more, of their income than the poor. Savings ratio is lower in poor countries than in rich countries, but does not rise linearly as income increases. This increases at a diminishing rate and then levels off (at approximately 25 percent of national income). In Levacic and Rebmann (2008), saving is the postponement of consumption in order to enjoy it at some future date, either directly oneself or through one's children.

Determinants of savings identified include the distribution of income, and the existence of financial institutions. Furthermore, the willingness to save is likely to be determined by the availability of financial institutions, and the range and availability of financial assets to suit savers with different needs. There is no single measure that can capture these institutional determinants of the willingness to save. The number, diversity and distribution of financial institutions serving the different interests of savers could also be important.

\subsection{Determinants of Investment}

Investment theories can be traced to Keynesian era (1936), Keynes firstly identified an independent investment function in the economy. A central feature of the Keynesian analysis is the observation that although savings and investment must be identical, savings and investment decisions are, in general, taken by different decision makers and there is no reason why savings should equal investment. The next phase in the evolution of investment theory gave rise to the accelerator theory, which makes investment a linear proportion of changes in output. In the accelerator model, expectations, profitability and capital costs play no role. Keynesians have traditionally favored the accelerator theory of investment while disregarding the role of factor costs.

The accelerator model is the flexible accelerator model. The bases behind this model is that the larger the gap between the existing capital stock and the desired capital stock, the greater a firm's rate of investment. The hypothesis is that firms plan to close a fraction, of the gap between the desired capital stock, $\mathrm{K}^{*}$, and the actual capital stock, $\mathrm{K}$, in each period. This gives rise to a net investment equation of the form of:

$$
I=d\left(K^{*}-K-1\right)
$$

Where I = net investment, $\mathrm{K}^{*}=$ desired capital stock, $\mathrm{K}-1$ = last period's capital stock, and d $=$ partial adjustment coefficient. Some economists have formulated the neoclassical approach, 
which is a version of the flexible accelerator model. In this approach, the desired or optimal capital stock is proportional to output and the user cost of capital (which in turn depends on the price of capital goods, the real rate of interest, the rate of depreciation and the tax structure).

Premised on the "Q" theory of investment (which is also in the neoclassical framework), the ratio of the market value of the existing capital stock to its replacement cost (the "Q" ratio) is the main force driving investment. It is clear from this section that the determinants of investment include the growth rate of GDP, internal funds (for example, change in credit to the private sector) and capacity utilization, other determinants of investment are the real rate of interest, user cost of capital and public investment ratio.

\subsection{Model Specification}

In an attempt to model the determinant of savings and investment in Nigeria economy, the model for this study is specified thus:

$$
G N S=f(I N T, S D R, I N F, G D P, A D)
$$

The model is therefore presented in a linear form as follows:

$$
G N S=\alpha_{0}+\alpha_{1} I N T+\alpha_{2} S D R+\alpha_{3} I N F+\alpha_{4} G D P+\alpha_{5} A D+U
$$

Here, gross national savings (GNS) is expressed as a function of interest rate (INT), savings deposit rate (SDR) and inflation rate (INF).

$$
I_{t}=f_{2}\left(R Y_{t}, L R_{t}, G N S, I N F\right)
$$

The model is therefore presented in a linear form as follows:

$$
I_{t}=\beta_{0}+\beta_{1} L R_{t}+\beta_{2} R Y_{t}+\beta_{3} G N S+\beta_{4} I N F+U
$$

\section{Data Analysis and Discussion of Results}

\subsection{Descriptive Analysis}

We use the mean of the variables, figure 1a shows the bar chart format of the means of all the variables which explains the trend in savings and investment as well as other variables. 


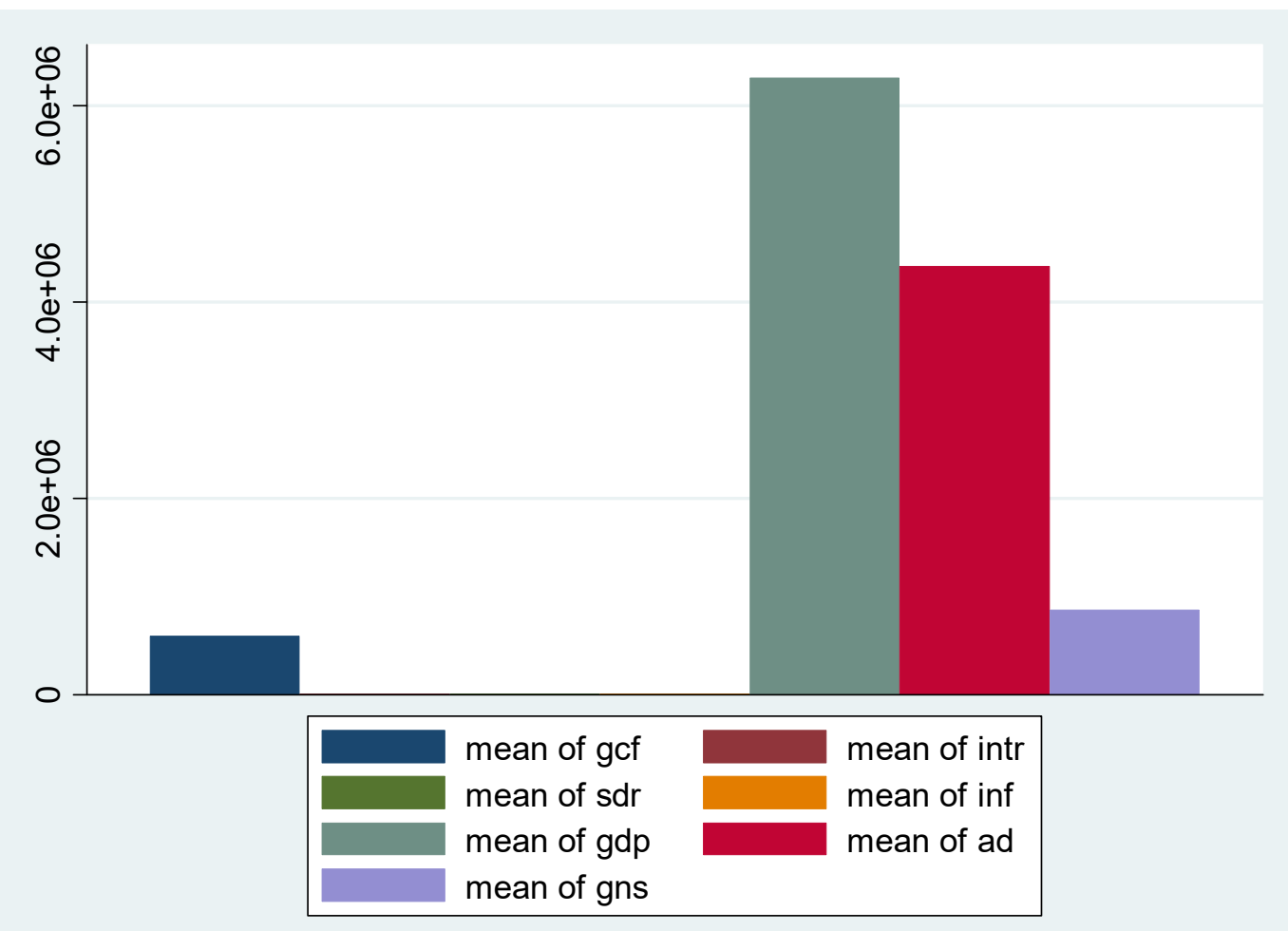

The mean analysis shows that gdp has the highest mean value, follow by aggregate consumption. The gcf and gns almost have the same level of mean.

\subsection{Unit Root Test}

The result of the unit root test is presented in Table 1.

Table 1. Stationarity test

\begin{tabular}{|c|c|c|}
\hline Variables & ADF Test statistics & Order of integration \\
\hline Lgcf & -3.671 & $\mathrm{I}(1)$ \\
\hline Lgns & -3.891 & $\mathrm{I}(1)$ \\
\hline Intr & -8.570 & $\mathrm{I}(1)$ \\
\hline Inf & -5.169 & $\mathrm{I}(1)$ \\
\hline Sdr & -5.663 & $\mathrm{I}(1)$ \\
\hline Lgdp & -4.300 & $\mathrm{I}(1)$ \\
\hline Lad & -4.351 & $\mathrm{I}(1)$ \\
\hline
\end{tabular}

Source: author's computation, 2013.

The result of the augmented Dickey fuller $\{\mathrm{ADF}\}$ unit root test is presented above from the result, all of the variables are non-stationary series but they are all stationary at first difference hence they are all I(1) series that is they are all integration of order one. The condition for testing for co integration has been met. The idea behind co integration is that 
even if some variables are not stationary their linear combination may be stationary after all. The existence of co integration confirms co-movement among the variables and consequently long run relationship exists among the variables.

Being a multivariate function, Johansen methods of co integration is employed and the result for the first model which uses GNS as the dependent variable is presented in Table 2.

Table 2. Johansen Co integration test for model 1

\begin{tabular}{|l|l|l|}
\hline Trace statistics Value & $5 \%$ Critical Value & Maximum Rank \\
\hline $138.8498^{* *}$ & 94.15 & 0 \\
\hline $78.9878^{* *}$ & 68.52 & 1 \\
\hline 40.3154 & 47.21 & 2 \\
\hline 18.2343 & 29.68 & 3 \\
\hline
\end{tabular}

Source: Author's Computation, 2013.

Note. $\left\{{ }^{* *}\right\}$ denotes rejection of the hypothesis at $5 \%$ level of significance.

The result of the Johansen co-integration test presented above indicates at least two co-integration equations. The result therefore confirms the existence of co integration among the variables. Consequently we can conclude that there exist a long run relationship between savings that is gross national savings (gns) and its determinants in Nigeria.

The next is the co-integration test for the second model. That is the model that uses gross capital formation (gcf) as the dependent variable. The result is presented in Table 3 .

Table 3. Johansen Co integration test for model 2

\begin{tabular}{|c|c|c|}
\hline Trace statistics Value & 5\% Critical Value & Maximum Rank \\
\hline $129.5249^{* *}$ & 94.15 & 0 \\
\hline $78.6643 * *$ & 68.52 & 1 \\
\hline $50.3938^{* *}$ & 47.21 & 2 \\
\hline 27.4212 & 29.68 & 3 \\
\hline
\end{tabular}

Source: Author's Computation, 2013.

Note. $\left\{{ }^{* *}\right\}$ denotes rejection of the hypothesis at $5 \%$ level of significance.

The result of the Johansen co-integration test presented above indicates at least three co-integration equations. The result therefore confirms the existence of co integration among the variables. Consequently we also can conclude that there exist a long run relationship between investment that is gross capital formation (gcf) and its determinants in Nigeria. 
To examine the long run relationship between savings and its determinants, the estimated regression equation is presented in Table 4.

Table 4. Normalised regression equation for log of gross national savings (lgns) Model 1

\begin{tabular}{|c|c|c|}
\hline Variables & Coefficients & Std error \\
\hline Intr & -.044586 & .0273907 \\
\hline Sdr & .0255049 & .0274534 \\
\hline Inf & -.0026504 & .0041465 \\
\hline Lgdp & $1.736367 * *$ & .6709425 \\
\hline Lad & -.7392941 & .6537176 \\
\hline Constant & -1.926531 & .7535454 \\
\hline
\end{tabular}

Note. ${ }^{* * *}$ Statistical significance at $1 \%, * *$ Statistical significance at $5 \%, \mathrm{~F}(5,24)=175.70$. Prob $>\mathrm{F}=0.0000$ R-squared $=0.9734$.

Source: Authors computation, 2013.

The result in Table 4 explains the linear relationship between savings and its determinants in Nigeria. The result shows that interest rate has an inverse relationship with savings, likewise inflation rate and aggregate consumption in Nigeria. All these are in line with the expected relationship (a priori expectation). The saving deposit ratio shows a direct relationship this is also the same form of relationship obtained for gross domestic product. However, the regression result is an indication that in the long run only the GDP has significant impact on savings. This is because among all the identified determinants only the coefficient of GDP is statistically significant. More importantly, the R square of 0.9734 shows that about $97 \%$ variation in savings is explained by the determinants. This is an indication that all the identified determinants are truly desirable in the model. In the same vein, the F test which examines the overall significance of the model is an indication that the estimated model is statistically significant at $1 \%$ level. This shows that all the identified determinants jointly have significant impact on savings in Nigeria.

The next analysis is of the long run relationship between investment and its determinants. The result is shown in Table 5.

Table 5. Normalised regression equation for log of gross capital formation (lgcf) Model 2

\begin{tabular}{|c|c|c|}
\hline Variables & Coefficients & Std error \\
\hline Intr & -.0206593 & .0204998 \\
\hline Sdr & .0074268 & .0205466 \\
\hline Inf & -.0032788 & .0031033 \\
\hline Lgdp & $1.94036^{* *}$ & .5021471 \\
\hline
\end{tabular}




\begin{tabular}{|c|c|c|}
\hline Lad & $-1.04897^{* *}$ & .4892556 \\
\hline Constant & -.7401678 & .5639687 \\
\hline
\end{tabular}

Note. ${ }^{* * *}$ Statistical significance at $1 \%, * *$ Statistical significance at $5 \%, F(5,24)=259.40$ Prob $>F=0.0000$ R-squared $=0.9818$.

Source: Authors computation, 2013.

Table 5 shows the long run relationship between investment and the identified determinants. The result indicates that all the determinants have the expected relationship with investment. For instance, interest rate has an inverse relationship likewise inflation rate and consumption. But gross domestic product and saving deposit ratio both have positive relationship. The result further shows that only the GDP and aggregate consumption have individual significant impact on investment among all the determinants. This is an indication that a rise in the GDP can significantly increase investment in Nigeria. Again, a rise in the aggregate consumption can significantly reduce investment in Nigeria as well. Similarly, the R square is very high. It shows that the determinants explained about 98\% variation in investment in Nigeria. The $\mathrm{F}$ test indicates that the model is statistically significant. Therefore all the dependent variables used as determinants are true variables that can jointly influence investment significantly in Nigeria.

\subsection{Error Correction Model}

The study investigates the short run dynamics among the variables. Firstly, we start with the first model.

Assessment of the short run dynamics between saving and its determinants.

Table 6. Error correction model for log of gross national savings (lgns) Model 1

\begin{tabular}{|c|c|c|}
\hline Variables & Coefficients & Std error \\
\hline D.lgns & $-.5843122^{* * *}$ & .0204998 \\
\hline D.Intr & $-.0206593^{* * *}$ & .0204998 \\
\hline D.Sdr & $.0530097 * * *$ & .003959 \\
\hline D.Inf & $-.0106895 * * *$ & .000581 \\
\hline D.lgdp & $-.7085661 * * *$ & .1116055 \\
\hline D.lad & $1.060588 * * *$ & .100984 \\
\hline Ecm & $-.6053531 * * *$ & .0488821 \\
\hline Constant & -.7401678 & .5639687 \\
\hline
\end{tabular}

Note. ${ }^{* * *}$ Statistical significance at $1 \%, * *$ Statistical significance at $5 \%, \mathrm{~F}(5,24)=259.40 \mathrm{Prob}>\mathrm{F}=0.0000$ R-squared $=0.9818$.

Source: Authors computation, 2013. 


\section{Macrothink}

Issues in Economics and Business

ISSN 2377-2301

2015, Vol. 1, No. 2

The error correction model result shows the short run dynamics between savings and its determinants. The result indicates that all the determinants are statistically significant in the short run. The ECM coefficient is also significant which implies that the error correction can play the adjustment role very well. It indicates that about $60 \%$ feedback from past disequilibrium is corrected at the present.

This is evident from the individual statistical significance of each determinant. Only one that is GDP is significant in the long run equation but in the short run equation all of them are significant individually. It is an indication that all these determinants have more of short run effect that is transitory effect on savings than long run or permanent effect.

Assessment of the short run dynamics between investment and its determinants.

Table 7. Error correction model for log of gross capital formation (lgcf) Model 2

\begin{tabular}{|c|c|c|}
\hline Variables & Coefficients & Std error \\
\hline D.lgcf & $.675849 * * *$ & $6.18 \mathrm{e}-07$ \\
\hline D.Intr & $.0206397 * * *$ & $4.18 \mathrm{e}-06$ \\
\hline D.Sdr & $-.0074002 * * *$ & $4.26 \mathrm{e}-06$ \\
\hline D.Inf & $.0032755 * * *$ & $3.84 \mathrm{e}-07$ \\
\hline D.lgdp & $-1.940214 * * *$ & .0000795 \\
\hline D.lad & $1.048927 * * *$ & .0000717 \\
\hline Ecm & $-.000162 * * *$ & .000034 \\
\hline Constant & -.0000213 & .0004687 \\
\hline
\end{tabular}

Note. ${ }^{* * *}$ Statistical significance at $1 \%, * *$ Statistical significance at $5 \%, \mathrm{~F}(5,24)=175.70$. Prob $>\mathrm{F}=0.0000$ R-squared $=0.9734$.

Source: Authors computation, 2013.

The error correction model result shows the short run dynamics between investment and its determinants. The result also indicates that all the determinants are statistically significant in the short run. The ECM coefficient is also significant which implies that the error correction can play the adjustment role very well. It indicates that about $60 \%$ feedback from past disequilibrium is corrected at the present.

This is evident from the individual statistical significance of each determinant. Only two that is GDP and LAD are significant in the long run equation but in the short run equation all of them are significant individually. It is an indication that all these determinants have more of short run effect that is transitory effect on investment than long run or permanent effect on investment in Nigeria.

\subsection{Discussion of Research Findings}

The null hypothesis posed at the introduction of this research work is: There is no 
relationship between aggregate savings and real disposable income proxy by GDP. After subjecting this hypothesis through the econometric methodology to research, we came to the following research findings: From the regression result shows that GDP conforms to a priori expectation under the study period, which requires it to be both positive and statistically significant thereby rejecting the null hypothesis that there is no relationship between aggregate savings and real disposable income proxy by GDP and accepting that there is a statistically significant impact of GDP on savings in the Nigeria economy. This finding is consistent with what Soyibo and Adekanye (1991) found out that GDP is significant in savings determination in Nigeria as reviewed in the chapter two of this research work. The result shows that interest rate has an inverse relationship with savings, likewise inflation rate and aggregate consumption in Nigeria. All these are in line with the expected relationship (a priori expectation). The saving deposit ratio shows a direct relationship this is also the same form of relationship obtained for gross domestic product. However, the regression result is an indication that in the long run only the GDP has significant impact on savings. This is because among all the identified determinants only the coefficient of GDP is statistically significant. More importantly, the $\mathrm{R}$ square of 0.9734 shows that about $97 \%$ variation in savings is explained by the determinants. This is an indication that all the identified determinants are truly desirable in the model.

The second null hypothesis posed at the introduction of this research work is: There is no relationship between investment and savings. After subjecting this hypothesis through the econometric methodology to research, we came to the following research findings: the regression result shows that there is a significant relationship between investment and savings in the Nigeria economy within the study period, we hereby reject the null hypothesis $\mathrm{H}_{0}$ and accept the alternative hypothesis $\mathrm{H}_{1}$. This shows that savings is a core determinant of investment within the study period, while other variables identified in this model as determinants of savings in the Nigeria economy appears also to be important factors that determines saving but has no significant impact on savings within the study period. The result also reveals that a statistically significant relationship exists between gross national savings and economic growth proxy by GDP in the first model presented in the model.

\subsection{Short Run Granger Causality Test}

To further investigate the relationship between saving and its determinants as well as investment and its determinants we explore their short run granger causality relationship.

The result of the causality test shows that there exist a bidirectional causality between interest rate and gcf. This further explains the relationship existing between investment and interest rate. Another variable that shows a very strong linkage with investment is gdp the result also show that there exist bidirectional causality between them too. Considering the savings model, the interest rate has a unidirectional relationship with it flowing from interest rate to gns. Again saving deposit ratio showed a very strong relationship with gns infer a bidirectional relationship. GDP also shows a bidirectional relationship with savings.

In summary, it can be concluded that the major factor influencing both gcf and gns in Nigeria is the gdp. While interest rate and saving deposit ratio are also strong determinants of both 
savings and investment. Aggregate consumption also has a strong linkage with the two inform of unidirectional relationship. Inflation rate appears to be a weak determinant of both savings and investment in Nigeria.

\section{Conclusion}

For a country to attain the desired level of growth and development there is the need for adequate capital formation, which in turn, depends on the level of savings in the economy. The importance of capital formation lies in the fact that it enhances the productivity of workers and greater rate of growth of per capita income. Despite the fact that capital formation is essential for growth and development, the situation in Nigeria is such that the level of savings is still poor and therefore affected capital formation. This low-level savings has led to low investment, negative real GDP growth, a decline in per capita GNP and other unpleasant macroeconomic developments in the Nigerian economy. Since income is not a main determinant of savings as the study indicates, the policy implication is that interest rate policy rather than income policy would be more vibrant in rekindling savings in the Nigerian economy.

Table 7. Granger Causality test

\begin{tabular}{|l|l|l|}
\hline Hypotheses: & F Statistics & Probability \\
\hline Interest rate does not granger cause gcf & 0.35 & 0.026 \\
\hline Gross capital formation does not granger cause interest rate & -0.19 & 0.715 \\
\hline inflation rate does not granger cause Gross capital formation & 3.4641 & 0.132 \\
\hline Gross capital formation rate does not granger cause Inflation Rate & .9081 & 0.626 \\
\hline consumption does not granger cause Gross capital formation & 5.5852 & 0.046 \\
\hline gdp does not granger cause gcf & 8.31 & 0.054 \\
\hline gcf does not granger cause GDP & 9.2603 & 0.046 \\
\hline gns does not granger cause interst rate & 9.786 & 0.015 \\
\hline Interest rate does not granger cause gns & 5.04 & 0.214 \\
\hline GDP not granger cause gns & 8.2903 & 0.018 \\
\hline gns does not granger cause GDP & 4.4681 & 0.097 \\
\hline Interest rate does not granger cause gns & 9.64121 & 0.086 \\
\hline gns does not granger cause interst Rate & .89685 & 0.639 \\
\hline Saving deposit ratio does not granger gns & 10.20694 & 0.002 \\
\hline consumption does not granger cause gns & 7.9860 & 0.0678 \\
\hline gns does not granger cause consumption & 0.9867 & 0.8967 \\
\hline gns does not granger cause saving deposit ratio & 15.278 & 0.000 \\
\hline inflation rate does not granger cause gns & 6.4296 & 0.040 \\
\hline gns does not granger cause inflation rate & 0.9867 & 0.7689 \\
\hline
\end{tabular}

In the light of the findings, which emerged in this study, the following recommendations are 
made - The Federal Government needs to promote investment in both physical and human capital in the country through compulsory savings and adequate investment in schools. Vibrant measures need to be put in place to speed up the process of economic development in Nigeria. In the light of inadequate domestic investment, government needs to emphasize the role of FDI in the country. The government also needs to focus attention on domestic resource mobilization. This will go a long way in promoting growth and development in Nigeria.

\section{References}

CBN. (2010). Interest Rate Management in Nigeria. CBN Briefs: Central Bank of Nigeria.

Chete, L. N. (1997). Understanding Private Savings Behaviour in Nigeria': An Empirical Analysis. Annals of the Social Science Council of Nigeria, 9(January-December).

Iyoha, M. A. (1998). Rekindling Investment for Economic Development in Nigeria: The Macroeconomic Issues: in Rekindling Investment for Economic Development in Nigeria. Nigerian Economic Society, Selected Papers for the 1998 Annual Conference.

Keynes, J. M. (1936). The General Theory of Employment, Interest and Money. London: Macmillan.

Levacic, R., \& Rebmann, A. (2008). Macroeconomics: An Introduction to Keynesian-Neoclassical Controversy. ELBS/Macmillan.

Lewis, A. (1970). The Theory of Economic Growth. New York: Harper and Row.

Nnanna, O. J. (2003). Promoting Savings and Investment Culture for National Development: Central Bank of Nigeria Economic and Financial Review, 4(3), September.

Nnanna, O. J. (2003). The Role of Central Bank of Nigeria in Enterprise Financing. Central Bank of Nigeria Bullion, 27(1), 19-28.

Nyong, M. O. (2000). Population Growth, Savings Rate and Economic Development in Nigeria. Dakar, Senegal Union for African Population Studies.

Oyaromade, R. (2005). Financial Sector Reforms and Financial Savings in Nigeria. Selected papers for the Nigerian Economic Society Conference, 427-448.

Reichel, R. (1991). The Macroeconomic Impact of Negative Real Interest Rates in Nigeria: Some Econometric Evidence. Savings and Development, XV(3), 273-283.

Soyibo, A., \& Adekanye, F. (1991). Financial System Regulation, Deregulation and Savings Mobilisation in Nigeria. African Economic Consortium, Research Paper, Final Report, Nairobi, Kenya.

Thirlwall, A. P. (1979). Growth and Development: With Special Reference to Developing Economies'(6th ed.).

Uchendu, O. A. (1993). Interest Rate Policy, Savings and Investments in Nigeria, Central Bank of Nigeria. Economic and Financial Review, 31(1). 


\section{Macrothink}

Issues in Economics and Business

ISSN 2377-2301

2015, Vol. 1, No. 2

Vaish, M. C. (2008). Macroeconomic Theory (12th ed.). Vikas Publishing House PVT 1td, New Delhi.

\section{Copyright Disclaimer}

Copyright for this article is retained by the author(s), with first publication rights granted to the journal. This is an open-access article distributed under the terms and conditions of the Creative Commons Attribution license (http://creativecommons.org/licenses/by/3.0/). 